\title{
Influence of rootstocks and pruning times on yield and on nutrient content and extraction in 'Niagara Rosada' grapevine
}

\author{
Marco Antonio Tecchio(1), Mara Fernandes Moura(2), Luiz Antonio Junqueira Teixeira ${ }^{(3)}$, \\ Erasmo José Paioli Pires ${ }^{(2)}$ and Sarita Leonel(1)
}

\begin{abstract}
(1)Universidade Estadual Paulista, Faculdade de Ciências Agronômicas, Departamento de Horticultura, Rua José Barbosa de Barros, no 1.780, CEP 18610-307 Botucatu, SP, Brazil. E-mail: tecchio@fca.unesp.br, sarinel@fca.unesp.br (2)Instituto Agronômico (IAC), Centro de Frutas, Avenida Luiz Pereira dos Santos, no 1.500, Corrupira, CEP 13214-820 Jundiaí, SP, Brazil. E-mail: mouram@iac.sp.gov.br, ejppires@iac.sp.gov.br (3)IAC, Centro de Solos e Recursos Ambientais, Avenida Barão de Itapura, no 1.481, Caixa Postal 28, Jardim Guanabara, CEP 13012-970 Campinas, SP, Brazil. E-mail: teixeira@iac.sp.gov.br
\end{abstract}

\begin{abstract}
The objective of this work was to evaluate the influence of rootstocks and pruning times on yield and on nutrient content and extraction by pruned branches and harvested bunches of 'Niagara Rosada' grapevine in subtropical climate. The rootstocks 'IAC 766', 'IAC 572', 'IAC 313', 'IAC 571-6', and '106-8 Mgt' were evaluated. Treatments consisted of a combination between five rootstocks and three pruning times. At pruning, fresh and dry matter mass of branches were evaluated to estimate biomass accumulation. At harvest, yield was estimated by weighing of bunches per plant. Branches and bunches were sampled at pruning and at harvest, respectively, for nutrient content analysis. Nutrient content and dry matter mass of branches and bunches were used to estimate total nutrient extraction. 'Niagara Rosada' grapevine grafted onto the 'IAC 572' rootstock had the highest yield and dry matter mass of bunches, which were significantly different from the ones observed in 'Niagara Rosada'/'IAC 313'. 'Niagara Rosada' grafted onto the 'IAC 572' rootstock extracted the largest quantity of $\mathrm{K}, \mathrm{P}, \mathrm{Mg}, \mathrm{S}, \mathrm{Cu}$, and $\mathrm{Fe}$, differing from 'IAC 313' and 'IAC 766' in K and P extraction, and from '106-8 Mgt' in $\mathrm{Mg}$ and $\mathrm{S}$ extraction. Winter pruning results in higher yield, dry matter accumulation by branches, and total nutrient content and extraction.
\end{abstract}

Index terms: Vitis labrusca, Vitis vinifera, biomass accumulation, mineral nutrition, yield.

\section{Influência de porta-enxertos e épocas de poda na produtividade e no teor e na extração de nutrientes na videira 'Niagara Rosada'}

\begin{abstract}
Resumo - O objetivo deste trabalho foi avaliar a influência de porta-enxertos e épocas de poda na produtividade e no teor e na extração de nutrientes por ramos removidos pela poda e pelos cachos na colheita da videira 'Niagara Rosada', em clima subtropical. Foram avaliados os porta-enxertos 'IAC 766', 'IAC 572', 'IAC 313', 'IAC 571-6' e '106-8 Mgt'. Os tratamentos consistiram de combinação de cinco porta-enxertos e três épocas de poda. Na ocasião da poda, avaliaram-se a massa de matéria fresca e seca dos ramos para estimar o acúmulo de biomassa. Na colheita, estimou-se a produtividade pela pesagem dos cachos por planta. Amostraram-se ramos e cachos na ocasião da poda e no momento da colheita, respectivamente, para análise dos teores de nutrientes. $\mathrm{O}$ teor de nutrientes e a massa de matéria seca dos ramos e dos cachos foram utilizados para estimar a extração total de nutrientes. A videira 'Niagara Rosada' enxertada no porta-enxerto 'IAC 572' apresentou maior produtividade e massa de matéria seca dos cachos, as quais diferiram significativamente das observadas em 'Niagara Rosada'/'IAC 313'. 'Niagara Rosada' enxertada sobre o porta-enxerto 'IAC 572' extraiu maior quantidade de $\mathrm{K}, \mathrm{P}, \mathrm{Mg}, \mathrm{S}, \mathrm{Cu}$ e Fe, tendo diferido de 'IAC 313' e 'IAC 766' na extração de $\mathrm{K}$ e $\mathrm{P}$, e de '106-8 Mgt' na extração de Mg e S. As podas de inverno resultam em maior produtividade, acúmulo de matéria seca nos ramos, teor e extração total de nutrientes.
\end{abstract}

Termos para indexação: Vitis labrusca, Vitis vinifera, acúmulo de biomassa, nutrição mineral, produtividade.

\section{Introduction}

In Brazil, the state of São Paulo is the second largest producer of table grapes. In the 2007/2008 crop season, the municipality of Jundiaí, located in the state of São Paulo, had 284 crop production units dedicated to viticulture, and 732.1 ha were destined for grape growing (Verdi et al, 2010).

Several studies were carried out to assess the behavior of 'Niagara Rosada' grapevine (Vitis labrusca L. x

Pesq. agropec. bras., Brasília, v.49, n.5, p.340-348, maio 2014

DOI: 10.1590/S0100-204X2014000500003 
Vitis vinifera L.) grafted onto different rootstocks, evaluating their influence on vegetative growth, yield, bunch characteristics, and phenology (Pauletto et al., 2001; Terra et al., 2003; Mota et al., 2009; Ribeiro et al., 2009; Rizk-Alla et al., 2011; Tecchio et al., 2011a, 2013; Tofanelli et al., 2011). As to nutritional aspects, rootstocks vary greatly in vigor due to different nutritional demands and water and nutrient uptake capacity, since their roots, depending on the variety, are selective for ion uptake from the soil solution, mainly in subtropical climate (Werle et al., 2008). Changes in the nutritional aspects of the plant according to the used rootstock have also been reported (Albuquerque \& Dechen, 2000; Giovannini et al., 2001; Tecchio et al., 2007, 2011b; Csikász-krizsics \& Diófási; 2008; Miele et al., 2009; Bettoni et al., 2013).

For grapevine, knowing the quantity of nutrients extracted by bunches and branches is essential, since these values allow determining the crop's macro- and micronutrient demands in descending order, which contributes to fertilization programs. The quantity of nutrients extracted by the grapevine is influenced by several factors, among which are variations in the canopy and the used rootstock (Tecchio et al., 2011a).

Albuquerque \& Dechen (2000) assessed the macronutrient uptake efficiency of the following grapevine rootstocks: 'IAC 313', 'IAC 572', 'IAC 766', 'Dog Ridge', 'Salt Creek', and 'Harmony', and concluded that biomass production highly correlates with the accumulated nutrient quantity. In the Serra Gaúcha region, in southern Brazil, Giovannini et al. (2001) evaluated the nutrient extraction by bunches, limbs, petioles, and branches of 12 'Cabernet Sauvignon' vineyards with yield above $15 \mathrm{Mg} \mathrm{ha}^{-1}$. Nutrient extraction by branches and bunches showed the following nutrient extraction scale: $\mathrm{K}>\mathrm{N}>\mathrm{Ca}>\mathrm{P}>\mathrm{Mg}>\mathrm{S}>\mathrm{Cu}>\mathrm{Mn}>\mathrm{Fe}>\mathrm{Zn}>\mathrm{B}$. Considering nutrient extraction by branches and bunches, the following quantities of nutrients were extracted from the grape bunches: $61 \% \mathrm{~N}, 65 \% \mathrm{P}, 73 \% \mathrm{~K}, 31 \% \mathrm{Ca}$, $44 \% \mathrm{Mg}, 65 \% \mathrm{~S}, 66 \% \mathrm{~B}, 67 \% \mathrm{Cu}, 81 \% \mathrm{Fe}, 31 \% \mathrm{Mn}$, and $26 \% \mathrm{Zn}$.

A nutritional survey conducted by Tecchio et al. (2007) in Jundiaí showed higher P, Fe, and $\mathrm{Zn}$ extraction by bunches of 'Niagara Rosada' when grafted onto the '106-8 Mgt' rootstock, and higher Mn extraction when grafted onto 'IAC 766'. On both rootstocks, 'Niagara Rosada' showed the following scale of nutrient accumulation by bunches:
$\mathrm{K}>\mathrm{N}>\mathrm{P}>\mathrm{Ca}>\mathrm{S}>\mathrm{Mg}>\mathrm{B}>\mathrm{Fe}>\mathrm{Mn}>\mathrm{Cu}>\mathrm{Zn}$. Miele et al. (2009) studied the effect of rootstocks on the nutrient content of 'Cabernet Sauvignon' grapevine tissues and detected variations in $\mathrm{N}, \mathrm{P}, \mathrm{K}, \mathrm{Ca}$, and $\mathrm{Mg}$ levels in the limbs, petioles, rachis, and berries; this effect varied with the nutrient and the tissue. When evaluating the effect of rootstocks on 'Niagara Rosada' grapevine grown in Votuporanga, in the state of São Paulo, Tecchio et al. (2011b) found that, depending on the used rootstock, yield ranged from 19.6 to $28.8 \mathrm{Mg} \mathrm{ha}^{-1}$, the dry mass accumulated by branches varied from 1,529 to $2,079 \mathrm{~kg} \mathrm{ha}^{-1}$, and the extracted mean content of N, K, P, $\mathrm{Mg}, \mathrm{Ca}$, and $\mathrm{S}$ was $47,84,8.4,20,6.3$, and $4.4 \mathrm{~kg} \mathrm{ha}^{-1}$, respectively, whereas those of $\mathrm{B}, \mathrm{Cu}, \mathrm{Fe}, \mathrm{Mn}$, and $\mathrm{Zn}$ were $70,23,215,812$, and $108 \mathrm{~g} \mathrm{ha}^{-1}$, respectively. The scale of total nutrient extraction by branches and bunches was: $\mathrm{K}>\mathrm{N}>\mathrm{Ca}>\mathrm{P}>\mathrm{Mg}>\mathrm{S}>\mathrm{Mn}>\mathrm{Fe}>\mathrm{Zn}>\mathrm{B}>\mathrm{Cu}$.

In the region of Jundiaí, production pruning is carried out from July to September and is called winter pruning. Currently, summer pruning is frequent in that region, and it is carried out after winter pruning harvest, from December to February, to reduce market prices and obtain more harvests in a shorter period. However, there is no known information in the literature about the nutrient content and the extraction of 'Niagara Rosada' grapevine considering this pruning modality, especially when different rootstocks are used. In Brazil, good results were obtained by Abrahão et al. (2002) in the state of Minas Gerais, Souza \& Fochesato (2007) in the state of Rio Grande do Sul, and Hernandes et al. (2013) in the state of São Paulo, when summer pruning was adopted for the Niagara Rosada and Niagara Branca cultivars, which allowed a second harvest from March to May, representing an alternative to expand the product-offering period.

The objective of this work was to evaluate the influence of rootstocks and pruning times on yield, nutrient content and extraction by pruned branches and harvested bunches of 'Niagara Rosada' grapevine in subtropical climate.

\section{Materials and Methods}

The experiment was performed in the municipality of Louveira, in the state of São Paulo, Brazil $\left(23^{\circ} 04^{\prime} \mathrm{S}\right.$, $46^{\circ} 55^{\prime} \mathrm{W}$, at $766 \mathrm{~m}$ altitude). Average annual rainfall at the experimental site was $1,400 \mathrm{~mm}$ and mean temperature was $19.5^{\circ} \mathrm{C}$, with $70.6 \%$ relative humidity. According to Köppen's classification, the climate 
is Cwa (subtropical climate). The three-year-old vineyard was supported by a trellis system, and plants were spaced at $1.7 \times 0.9 \mathrm{~m}$, at a density of 6,536 plants per hectare.

The experimental design was randomized complete block in a split-plot arrangement, with five replicates. The plots were composed of rootstocks, and the split-plot of pruning times. Each experimental plot included five plants. Treatments consisted of a combination of five rootstocks for 'Niagara Rosada' and three pruning times. The rootstocks evaluated were: 'IAC 766', 'IAC 572', 'IAC 313', 'IAC 571-6', and '106-8 Mgt'. The assessed pruning times were: winter pruning, on August 31 $1^{\text {st }}, 2009$ (first), and on September $22^{\text {nd }}, 2010$ (third); and summer pruning, on January $1^{\text {st }}$, 2010 (second). In winter, short pruning was performed, leaving only one bud in the production branch. In summer, four to five buds were kept. In all the three pruning times, 5\% hydrogen cyanamide was applied after pruning.

Soil chemical analysis at $30 \mathrm{~cm}$ from the planting line and at $0-20 \mathrm{~cm}$ depth indicated: $5.6 \mathrm{pH}\left(\mathrm{CaCl}_{2}\right) ; 30$ $\mathrm{g} \mathrm{dm}^{-3}$ organic matter; $400 \mathrm{mg} \mathrm{dm}^{-3} \mathrm{P} ; 3.2 \mathrm{mmol}_{\mathrm{c}} \mathrm{dm}^{-3}$ $\mathrm{K} ; 73 \mathrm{mmol}_{\mathrm{c}} \mathrm{dm}^{-3} \mathrm{Ca} ; 16 \mathrm{mmol}_{\mathrm{c}} \mathrm{dm}^{-3} \mathrm{Mg} ; 20 \mathrm{mmol}_{\mathrm{c}}$ $\mathrm{dm}^{-3} \mathrm{H}+\mathrm{Al} ; 92.2 \mathrm{mmol}_{\mathrm{c}} \mathrm{dm}^{-3}$ base saturation; 112.4 $\mathrm{mmol}_{\mathrm{c}} \mathrm{dm}^{-3}$ cation exchange capacity; $82 \%$ base saturation percentage; $0.23 \mathrm{mg} \mathrm{dm}^{-3} \mathrm{~B} ; 15.6 \mathrm{mg} \mathrm{dm}^{-3}$ $\mathrm{Cu} ; 49 \mathrm{mg} \mathrm{dm}^{-3} \mathrm{Fe} ; 27.9 \mathrm{mg} \mathrm{dm}^{-3} \mathrm{Mn}$; and $9 \mathrm{mg} \mathrm{dm}^{-3} \mathrm{Zn}$.

Regarding fertilization, $3 \mathrm{~kg}$ per plant of composted poultry litter $\left(1.0 \% \mathrm{~N}, 2.2 \% \mathrm{P}_{2} \mathrm{O}_{5}\right.$, and $1.0 \% \mathrm{~K}_{2} \mathrm{O}$ approximately) and $300 \mathrm{~g}$ per plant of magnesian thermophosphate $\left(\begin{array}{lllll}18 \% & \mathrm{P}_{2} \mathrm{O}_{5} & \text { and } & 7 \% & \mathrm{Mg}\end{array}\right)$ were applied to the inter-rows of planting groves, in May 2009 and 2010. In all the three production cycles, a cover fertilization was done at the beginning of sprouting, with $90 \mathrm{~g}$ per plant of calcium nitrate, and at the groat-sized berries stage, with $100 \mathrm{~g}$ per plant of 20-0-20 ( $\left.-\mathrm{P}_{2} \mathrm{O}_{5}-\mathrm{K}_{2} \mathrm{O}\right)$.

After pruning, the total fresh mass of removed branches was assessed for each experimental plot. Then, samples of two branches per plant were sent to the laboratory and subjected to washing and drying in a forced-air oven $\left(65\right.$ to $\left.70^{\circ} \mathrm{C}\right)$ in order to obtain the branch dry mass percentage. Therefore, biomass accumulation was estimated by multiplying the dry mass percentage of the sample by the total fresh mass of pruned branches. Subsequently, chemical analysis for branch nutrients was carried out to determine N, P, $\mathrm{K}, \mathrm{Ca}, \mathrm{Mg}, \mathrm{S}, \mathrm{B}, \mathrm{Cu}, \mathrm{Fe}, \mathrm{Mn}$, and $\mathrm{Zn}$ levels according to the methodology described by Malavolta et al. (1997). The product of the nutrient content of branch dry matter mass was used to estimate the nutrient exportation due to the removal of the pruned material in each experimental plot.

At harvest, to determine the number of bunches per plant and plant yield, the bunches of each plant of the experimental area were weighed. Five bunches per experimental plot were sampled and subjected to washing and drying in a forced-air oven, at 65 to $70^{\circ} \mathrm{C}$, during ten days, in order to obtain the dry matter mass percentage. Subsequently, the bunches were ground and subjected to chemical analysis of macro- and micronutrients, according to Malavolta et al. (1997). Nutrient extraction by bunches was obtained by multiplying the nutrient content by the total dry matter mass of bunches collected from each experimental plot. Total nutrient extraction was determined by summing the nutrient extraction by branches and bunches. Then, the percentage of nutrients removed by grape bunches was calculated based on the quotient between nutrients extracted by bunches and total nutrients extracted by the grapevine.

Data were subjected to analysis of variance, and means were compared by Tukey's test, at 5\% probability, using the Sisvar software, version 5.3 (Ferreira, 2011).

\section{Results and Discussion}

A significant effect of rootstocks and pruning times was observed on yield and dry matter mass of bunches and branches of 'Niagara Rosada' grapevine, with no interaction among factors. For 'Niagara Rosada' grapevine grafted onto the 'IAC 572' rootstock, the mean yield and bunch dry mass yield were significantly higher than those achieved with 'IAC 313' (Table 1). Pauletto et al. (2001) and Terra et al. (2003) also assessed the effect of different rootstocks on 'Niagara Rosada' grapevine, observing yields similar to those of 'Niagara Rosada' grafted onto the 'IAC 766' and '106-8 Mgt' rootstocks. These data show that the behavior of the combination between grapevine canopy and rootstock varies with the edaphoclimatic conditions of each region. Considering pruning times, winter pruning led to significantly higher mean yields than those observed for summer pruning. Similarly, Hernandes et al. (2013), when studying the production of 'Niagara 
Rosada' grapevine under different conduction systems, also found that yield was higher in winter pruning.

The 'IAC 572' rootstock provided the highest dry mass accumulation by 'Niagara Rosada' grapevine branches (Table 1). Albuquerque \& Dechen (2000) and Mota et al. (2009) also reported higher shoot dry mass accumulation with the 'IAC 572' rootstock, in comparison to 'IAC 766'. Tecchio et al. (2011b) concluded that the 'IAC 572' rootstock provided higher branch dry mass accumulation, compared to 'IAC 571-6'. Furthermore, Pauletto et al. (2001) obtained similar mass for pruned branches of 'Niagara Rosada' using the 'IAC 766' and 'IAC 313' rootstocks. The variations observed for 'Niagara Rosada' production and vigor were related to the interactions that occurred between the canopy and the assessed rootstocks. According to Hartmann \& Kester (1990), the most vigorous rootstocks showed higher water and nutrient uptake and translocation capacity, which contribute to greater canopy development. However, higher rootstock vigor is not related only to higher yield.

There was a significant influence of rootstocks and pruning times on $\mathrm{N}, \mathrm{K}, \mathrm{P}, \mathrm{Mg}$, and $\mathrm{Zn}$ content in branches, and $\mathrm{K}, \mathrm{Ca}, \mathrm{S}, \mathrm{Cu}, \mathrm{Fe}$, and $\mathrm{Zn}$ content in bunches of 'Niagara Rosada' grapevine (Table 2), with no interaction among factors. For branches, the highest levels were found for the following nutrients

Table 1. Yield and dry matter mass (DM) of bunches and branches of 'Niagara Rosada' grafted onto different rootstocks in three pruning times ${ }^{(1)}$.

\begin{tabular}{|c|c|c|c|c|}
\hline \multirow[t]{2}{*}{ Variable } & \multicolumn{2}{|c|}{ Yield } & \multirow{2}{*}{$\begin{array}{l}\text { DM Bunches } \\
\left(\mathrm{kg} \mathrm{h}^{-1}\right)\end{array}$} & \multirow{2}{*}{$\begin{array}{c}\text { DM Branches } \\
\left(\mathrm{kg} \mathrm{ha}^{-1}\right)\end{array}$} \\
\hline & $\left(\mathrm{Mg} \mathrm{ha}^{-1}\right.$ & g per plant) & & \\
\hline \multicolumn{5}{|l|}{ Rootstocks } \\
\hline 'IAC 313' & $14.2 \mathrm{~b}$ & $2.2 \mathrm{~b}$ & $2,454 b$ & $895 \mathrm{ab}$ \\
\hline 'IAC 572' & $18.7 \mathrm{a}$ & $2.9 \mathrm{a}$ & $3,216 \mathrm{a}$ & $1,167 \mathrm{a}$ \\
\hline 'IAC 571-6' & $17.8 \mathrm{ab}$ & $2.7 \mathrm{ab}$ & $2,974 a b$ & $733 b$ \\
\hline 'IAC 766' & $15.7 \mathrm{ab}$ & $2.4 \mathrm{ab}$ & $2,776 \mathrm{ab}$ & $759 b$ \\
\hline '106-8 Mgt' & $15.7 \mathrm{ab}$ & $2.4 \mathrm{ab}$ & $2,751 \mathrm{ab}$ & $809 \mathrm{~b}$ \\
\hline \multicolumn{5}{|l|}{ Pruning times } \\
\hline First (winter) & $15.3 b$ & $2.3 b$ & $2,346 b$ & $1,158 \mathrm{a}$ \\
\hline Second (summer) & $8.3 \mathrm{c}$ & $1.3 \mathrm{c}$ & $1,645 \mathrm{c}$ & $697 b$ \\
\hline Third (winter) & $25.7 \mathrm{a}$ & $3.9 \mathrm{a}$ & $4,512 \mathrm{a}$ & $763 \mathrm{~b}$ \\
\hline Mean & 16.4 & 2.5 & 2,834 & 872.4 \\
\hline CVrootstocks (\%) & 23.2 & 23.3 & 21.9 & 33.6 \\
\hline CVpruning (\%) & 22.0 & 21.8 & 22.0 & 16.7 \\
\hline
\end{tabular}

${ }^{(1)}$ Means followed by equal letters, in the columns, do not differ by Tukey's test, at $5 \%$ probability. $\mathrm{CV}$, coefficient of variation. and rootstocks: $\mathrm{N}$ with '106-8 $\mathrm{Mgt}$ ', 'IAC 766', and 'IAC 571-6'; K with 'IAC 572', 'IAC 313', and '106-8 Mgt'; P with '106-8 Mgt', 'IAC 766', 'IAC 572', and 'IAC 571-6'; Mg with 'IAC 766'; and Zn with 'IAC 571-6', 'IAC 766', and '106-8 Mgt'. These results are in agreement with those obtained by Tecchio et al. (2011b), who also reported that pruned branches of 'Niagara Rosada' grapevine grafted onto the 'IAC 766' rootstock had higher $\mathrm{N}$ and $\mathrm{Mg}$ levels and lower $\mathrm{K}$ levels, compared to branches of grapevine grafted onto 'IAC 313'. These observations also agree with the results of Wolpert et al. (2005), who attributed the variations to interactions between scion and rootstock and to the effects of climate and soil conditions.

Nutrient content in bunches varied significantly depending on the rootstock. The highest nutrient concentrations in bunches of 'Niagara Rosada' were: $\mathrm{K}$ with 'IAC 572'; $\mathrm{Ca}$ and $\mathrm{S}$ with 'IAC 313' and 'IAC 571-6'; Cu with 'IAC 572' and 'IAC 571-6'; and $\mathrm{Fe}$ and $\mathrm{Zn}$ with 'IAC 571-6'. Likewise, Tecchio et al. (2011b) found that the 'IAC 572' rootstock led to higher $\mathrm{K}$ content and lower $\mathrm{Ca}$ and $\mathrm{Zn}$ contents in bunches of 'Niagara Rosada' grapevine.

Nutrient content was higher in winter pruning, compared to summer pruning, in samples of branches and bunches, except for $\mathrm{K}, \mathrm{P}, \mathrm{B}$, and $\mathrm{Zn}$ levels in branches and $\mathrm{S}, \mathrm{B}, \mathrm{Cu}$, and $\mathrm{Mn}$ in bunches. The highest nutrient content in branches and bunches during winter pruning was due to the longer grapevine cycle in this period, compared to the production cycle in summer pruning. On average, the 'Niagara Rosada' grapevine cycle for the different rootstocks lasted 138 and 142 days during winter pruning and 123 days during summer pruning. The period of fertilization with organic compost and thermophosphate in May 2009 and 2010, preceding winter pruning, should also be considered. Therefore, at the beginning of sprouting in winter pruning, the quantity of nutrients available in the soil due to compost mineralization and fertilization is certainly higher than that obtained at the beginning of sprouting in summer pruning, when fertilization is not performed before pruning.

Differences in nutrient content according to the rootstock were also verified by Csikász-krizsics \& Diófási (2008), Miele et al. (2009), and Tecchio et al. (2011b). Those authors concluded that the variations in nutrient content for grapevine branches and bunches are probably due to the vigor and genetic origin of the rootstocks. According to Ibacache \& Carlos Sierra 
(2009), the use of rootstocks has an important influence on the mineral nutrition of the grafted variety. Nikolaou et al. (2003) emphasized that the uptake is related to an increased root hair density in response to the deficiency of a certain nutrient.

There was a significant influence of rootstocks and pruning times on $\mathrm{N}, \mathrm{K}, \mathrm{P}, \mathrm{Ca}, \mathrm{Mg}, \mathrm{S}, \mathrm{B}$, and $\mathrm{Zn}$ extraction by branches, and $\mathrm{K}$ and $\mathrm{Cu}$ extraction by bunches of 'Niagara Rosada' grapevine, and the highest values were mostly obtained with the 'IAC 572' rootstock (Table 3). These changes are due to rootstock effect on yield, dry matter mass of pruned branches (Table 1), and nutrient content of branches and bunches (Table 2) of 'Niagara Rosada' grapevine, since these factors are considered in the calculation of nutrient extraction. Nutrient extraction by 'Niagara Rosada' showed the following order: $\mathrm{N}>\mathrm{Ca}>\mathrm{K}>\mathrm{Mg}>\mathrm{P}>\mathrm{S}>\mathrm{Mn}>\mathrm{Zn}>\mathrm{Cu}>\mathrm{Fe}>\mathrm{B}$ for branches and $\mathrm{K}>\mathrm{N}>\mathrm{Ca}>\mathrm{P}>\mathrm{Mg}>\mathrm{S}>\mathrm{Cu}>\mathrm{B}>\mathrm{Fe}>\mathrm{Mn}>\mathrm{Zn}$ for bunches. Tecchio et al. (2007) carried out a nutritional survey in Jundiaí, and concluded that 'Niagara Rosada' grafted onto '106-8 Mgt' showed higher $\mathrm{P}, \mathrm{Fe}$, and $\mathrm{Zn}$ extraction by bunches, whereas Mn extraction was higher with 'IAC 766', resulting in a scale of nutrient extraction by bunches similar to that obtained in the present work. Tecchio et al. (2011b) observed higher macro- and micronutrient extraction by branches of 'Niagara Rosada' with 'IAC 572', differing significantly only from the 'IAC 571-6' rootstock. Albuquerque \& Dechen (2000) assessed the capacity of macronutrient uptake by grapevine rootstocks and also found higher nutrient accumulation for the 'IAC 572' rootstock, which extracted higher quantities of N, P, K, and Ca.

Considering the total nutrient extraction by branches and bunches, 'Niagara Rosada' grapevine grafted onto the 'IAC 572' rootstock extracted a higher quantity of $\mathrm{K}, \mathrm{P}, \mathrm{Mg}, \mathrm{S}, \mathrm{Cu}$, and $\mathrm{Fe}$, differing significantly from 'IAC 313' and 'IAC 766' in K and P extraction and from

Table 2. Content of macro- and micronutrients in branches and bunches of 'Niagara Rosada' grafted onto different rootstocks in three pruning times ${ }^{(1)}$.



${ }^{(1)}$ Means followed by equal letters, in the columns, do not differ by Tukey's test, at 5\% probability. CV, coefficient of variation. 
'106-8 Mgt' in Mg and S extraction (Table 4). Tecchio et al. (2011b) verified higher macro- and micronutrient extraction for 'Niagara Rosada' grafted onto 'IAC 766', which showed similar N, K, P, Ca, Mg, S, B, and $\mathrm{Cu}$ values, compared to the 'IAC 572' and 'IAC 313' rootstocks.

These data show that nutrient uptake and accumulation by the grapevine varied with the edaphoclimatic conditions of each region. Total nutrient extraction by branches and bunches of 'Niagara Rosada' grapevine showed the following nutrient extraction scale: $\mathrm{K}>\mathrm{N}>\mathrm{Ca}>\mathrm{P}>\mathrm{Mg}>\mathrm{S}>\mathrm{Cu}>\mathrm{Mn}>\mathrm{Fe}>\mathrm{B}>\mathrm{Zn}$. These results partially agree with those reported by Giovannini et al. (2001) and Tecchio et al (2011b), who observed the following order of nutrient extraction, respectively: $\mathrm{K}>\mathrm{N}>\mathrm{Ca}>\mathrm{P}>\mathrm{Mg}>\mathrm{S}>\mathrm{Mn}>\mathrm{Fe}>\mathrm{Zn}>\mathrm{B}>\mathrm{Cu}$ and $\mathrm{K}>\mathrm{N}>\mathrm{Ca}>\mathrm{P}>\mathrm{Mg}>\mathrm{S}>\mathrm{Mn}>\mathrm{Fe}>\mathrm{Zn}>\mathrm{B}>\mathrm{Cu}$. Bettoni et al. (2013), when evaluating 'Cabernet Sauvignon', found the following nutrient extraction: $\mathrm{K}>\mathrm{N}>\mathrm{P}>\mathrm{Ca}>\mathrm{Mg}$.
The mean values obtained for total nutrient extraction by branches and bunches of 'Niagara Rosada' grapevine were lower (Table 4) than the values reported by Tecchio et al. (2011b). This is mainly due to the differences in the used conduction systems and the planting densities at the experimental areas. In the present study, the trellis system was used and the planting density was of 6,536 plants per hectare, which resulted in a mean yield of $16.4 \mathrm{Mg} \mathrm{ha}^{-1}$ and a branch dry mass of $872 \mathrm{~kg} \mathrm{ha}^{-1}$ for 'Niagara Rosada'. However, in the experiment carried out by Tecchio et al. (2011b), the grapevines were supported by the pergola system and the planting density was of 2,500 plants per hectare, which led to a mean yield of $24.1 \mathrm{Mg} \mathrm{ha}^{-1}$ and a branch dry mass of 2,054 $\mathrm{kg} \mathrm{ha}^{-1}$. Therefore, a higher yield associated with a higher branch dry mass accumulation led to a higher nutrient extraction.

Data reported in the literature have shown values of $\mathrm{N}$ extracted by grapevine varying from 15 to $100 \mathrm{~kg} \mathrm{ha}^{-1}$,

Table 3. Removal of macro- and micronutrients by pruned branches and harvested bunches of 'Niagara Rosada' grafted onto different rootstocks in three pruning times ${ }^{(1)}$.

\begin{tabular}{|c|c|c|c|c|c|c|c|c|c|c|c|}
\hline \multirow[t]{2}{*}{ Variable } & $\mathrm{N}$ & $\mathrm{K}$ & $\mathrm{P}$ & $\mathrm{Ca}$ & $\mathrm{Mg}$ & $\mathrm{S}$ & B & $\mathrm{Cu}$ & $\mathrm{Fe}$ & $\mathrm{Mn}$ & $\mathrm{Zn}$ \\
\hline & \multicolumn{10}{|c|}{---------------------------------------(kg ha'1)------------------------------------ } & $---\cdot-$ \\
\hline Rootstocks & \multicolumn{11}{|c|}{ Nutrient removal by branches } \\
\hline 'IAC 313 ' & $6.6 \mathrm{ab}$ & $5.5 b$ & $1.0 \mathrm{ab}$ & $8.1 \mathrm{ab}$ & $1.4 \mathrm{ab}$ & $0.7 \mathrm{ab}$ & $12 \mathrm{ab}$ & $41 \mathrm{a}$ & $39 \mathrm{a}$ & $60 \mathrm{a}$ & $47 \mathrm{ab}$ \\
\hline 'IAC 572 ' & $8.9 \mathrm{a}$ & $8.8 \mathrm{a}$ & $1.5 \mathrm{a}$ & $9.7 \mathrm{a}$ & $1.9 \mathrm{a}$ & $1.0 \mathrm{a}$ & $16 a$ & $50 \mathrm{a}$ & $50 \mathrm{a}$ & $86 a$ & $64 a$ \\
\hline 'IAC 571-6' & $5.7 \mathrm{~b}$ & $4.3 b$ & $0.8 \mathrm{~b}$ & $6.4 \mathrm{ab}$ & $1.2 \mathrm{~b}$ & $0.6 \mathrm{~b}$ & $9 b$ & $40 \mathrm{a}$ & $34 \mathrm{a}$ & $53 a$ & $56 a b$ \\
\hline 'IAC 766' & $5.8 \mathrm{~b}$ & $4.6 \mathrm{~b}$ & $0.9 \mathrm{~b}$ & $6.0 \mathrm{~b}$ & $1.4 \mathrm{ab}$ & $0.6 \mathrm{~b}$ & $10 \mathrm{ab}$ & $45 \mathrm{a}$ & $30 \mathrm{a}$ & $67 \mathrm{a}$ & $44 b$ \\
\hline '106-8 Mgt' & $6.5 \mathrm{ab}$ & $5.1 \mathrm{~b}$ & $1.0 \mathrm{~b}$ & $6.5 \mathrm{ab}$ & $1.2 \mathrm{~b}$ & $0.7 \mathrm{~b}$ & $11 \mathrm{ab}$ & $36 a$ & $33 \mathrm{a}$ & $70 \mathrm{a}$ & $51 \mathrm{ab}$ \\
\hline \multicolumn{12}{|l|}{ Pruning times } \\
\hline First (winter) & $9.8 \mathrm{a}$ & $5.3 \mathrm{~b}$ & $1.5 \mathrm{a}$ & $11.0 \mathrm{a}$ & $1.9 \mathrm{a}$ & $1.0 \mathrm{a}$ & $16 \mathrm{a}$ & $16 b$ & $68 \mathrm{a}$ & $92 \mathrm{a}$ & $86 a$ \\
\hline Second (summer) & $4.7 \mathrm{c}$ & $7.3 \mathrm{a}$ & $0.8 \mathrm{~b}$ & $5.0 \mathrm{c}$ & $1.0 \mathrm{c}$ & $0.4 \mathrm{c}$ & $10 \mathrm{~b}$ & $25 b$ & $13 \mathrm{c}$ & $45 \mathrm{c}$ & $33 b$ \\
\hline Third (winter) & $5.7 \mathrm{~b}$ & $4.4 \mathrm{~b}$ & $0.8 \mathrm{~b}$ & $6.1 \mathrm{~b}$ & $1.3 \mathrm{~b}$ & $0.7 \mathrm{~b}$ & $9 \mathrm{~b}$ & $87 \mathrm{a}$ & $30 \mathrm{~b}$ & $64 b$ & $38 b$ \\
\hline Mean & 6.7 & 5.7 & 1.0 & 7.3 & 1.4 & 0.7 & 11.6 & 42.6 & 37.1 & 67.2 & 52.3 \\
\hline CVrootstocks (\%) & 38.5 & 48.3 & 40.4 & 43.0 & 36.2 & 36.1 & 45.8 & 45.6 & 47.7 & 55.9 & 33.7 \\
\hline CVpruning (\%) & 17.6 & 29.7 & 19.9 & 21.7 & 17.3 & 21.2 & 22.4 & 50.0 & 34.8 & 31.4 & 26.5 \\
\hline Rootstocks & \multicolumn{11}{|c|}{ Nutrient removal by bunches } \\
\hline 'IAC 313' & 15.4 & $38.7 \mathrm{~b}$ & $3.1 \mathrm{a}$ & $5.8 \mathrm{a}$ & $1.5 \mathrm{a}$ & $1.4 \mathrm{a}$ & $48 \mathrm{a}$ & $121 \mathrm{c}$ & $46 \mathrm{a}$ & $22 \mathrm{a}$ & $8 \mathrm{a}$ \\
\hline 'IAC 572' & 18.5 & $56.8 \mathrm{a}$ & $3.9 \mathrm{a}$ & $5.6 \mathrm{a}$ & $1.8 \mathrm{a}$ & $1.5 \mathrm{a}$ & $63 a$ & $179 \mathrm{ab}$ & $54 \mathrm{a}$ & $25 \mathrm{a}$ & $8 \mathrm{a}$ \\
\hline 'IAC 571-6' & 16.9 & $48.6 \mathrm{ab}$ & $3.9 \mathrm{a}$ & $6.6 \mathrm{a}$ & $1.7 \mathrm{a}$ & $1.6 \mathrm{a}$ & $49 a$ & $191 \mathrm{a}$ & $59 \mathrm{a}$ & $23 a$ & $10 \mathrm{a}$ \\
\hline 'IAC 766' & 16.2 & $45.0 \mathrm{ab}$ & $3.4 \mathrm{a}$ & $5.0 \mathrm{a}$ & $1.6 \mathrm{a}$ & $1.3 \mathrm{a}$ & $44 a$ & $126 \mathrm{c}$ & $43 \mathrm{a}$ & $20 \mathrm{a}$ & $8 \mathrm{a}$ \\
\hline '106-8 Mgt' & 15.7 & $45.5 \mathrm{ab}$ & $3.6 \mathrm{a}$ & $4.9 \mathrm{a}$ & $1.5 \mathrm{a}$ & $1.4 \mathrm{a}$ & $52 \mathrm{a}$ & $132 \mathrm{bc}$ & $41 \mathrm{a}$ & $21 \mathrm{a}$ & $8 \mathrm{a}$ \\
\hline \multicolumn{12}{|l|}{ Pruning times } \\
\hline First (winter) & $14.6 \mathrm{~b}$ & $38.8 b$ & $2.9 \mathrm{~b}$ & $3.9 \mathrm{~b}$ & $1.4 \mathrm{~b}$ & $1.3 \mathrm{~b}$ & $33 b$ & $125 \mathrm{~b}$ & $32 b$ & $13 b$ & $7 b$ \\
\hline Second (summer) & $7.6 \mathrm{c}$ & $24.4 \mathrm{c}$ & $1.7 \mathrm{c}$ & $2.6 \mathrm{~b}$ & $0.8 \mathrm{c}$ & $0.8 \mathrm{c}$ & $30 b$ & $96 b$ & $27 b$ & $16 b$ & $4 c$ \\
\hline Third (winter) & $27.3 \mathrm{a}$ & $77.4 \mathrm{a}$ & $6.1 \mathrm{a}$ & $10.3 \mathrm{a}$ & $2.7 \mathrm{a}$ & $2.2 \mathrm{a}$ & $90 \mathrm{a}$ & $229 a$ & $87 \mathrm{a}$ & $37 \mathrm{a}$ & $14 \mathrm{a}$ \\
\hline Mean & 16.5 & 46.9 & 3.6 & 5.6 & 1.6 & 1.4 & 51.2 & 149.8 & 48.5 & 22.1 & 8.5 \\
\hline CVrootstocks (\%) & 22.7 & 23.6 & 23.7 & 32.9 & 29.7 & 21.4 & 61.0 & 29.7 & 35.6 & 62.0 & 33.9 \\
\hline CVpruning (\%) & 25.9 & 22.2 & 26.2 & 32.9 & 29.8 & 24.6 & 51.5 & 33.0 & 38.7 & 49.3 & 41.1 \\
\hline
\end{tabular}

${ }^{(1)}$ Means followed by equal letters, in the columns, do not differ by Tukey's test, at 5\% probability. CV, coefficient of variation. 
and these variations are attributed to edaphoclimatic conditions, especially temperature and rainfall, as well as to changes in yield. Lower production is related to crops growing under dry climate, which slows down vegetative growth, limiting plant vigor (Giovaninni et al., 2001). While evaluating 'Niagara Rosada' grapevine, in the state of São Paulo, where high temperatures and humidity occur seasonally, Dechen et al (1979) verified a total annual extraction by the plant of $91 \mathrm{~kg} \mathrm{ha}^{-1} \mathrm{~N}$, which was higher than the value obtained in the present study, of $23 \mathrm{~kg} \mathrm{ha}^{-1}$ $\mathrm{N}$. This difference may be explained by the young age of the vineyard, three years old, and by the fact that $\mathrm{N}$ extraction was evaluated by considering only pruned bunches and branches. Bettoni et al. (2013) studied the nutrient extraction and exportation of 'Cabernet Sauvignon' grafted onto the 'Paulsen 1103' and 'VR 043-43' rootstocks and observed higher P extraction by the plant and higher $\mathrm{K}$ exportation by the clusters in plants grafted onto the 'VR 043-43' rootstock.

The mean $\mathrm{P}$ extraction was low in comparison to that of the other nutrients; however, it is within the range cited by Giovaninni et al. (2001), who reported variations from 2 to $15.3 \mathrm{~kg} \mathrm{ha}^{-1}$ for vineyards from different countries, conditioned to soil fertility and yield. According to those authors, a low total extraction of this nutrient is likely due to a low need of $\mathrm{P}$ by the grapevine.

Potassium was the most extracted nutrient. Several studies point out the same tendency, since $\mathrm{K}$ is found at large quantities in grape bunches and its total extraction is directly linked to fruit production per hectare. Fregoni (1984) reported values of K extraction ranging from 34 to $123 \mathrm{~kg} \mathrm{ha}^{-1}$ for yields from 7 to $25 \mathrm{Mg} \mathrm{ha}^{-1}$; the data obtained in the present study agree with those values.

There was no effect of rootstock on the percentage of macro- and micronutrient extraction by bunches, regarding the total nutrients exported by 'Niagara Rosada' (Table 5). Considering the mean values observed for total nutrient extraction of 'Niagara Rosada' grafted onto different rootstocks, the following were exported for grape bunches: $71 \% \mathrm{~N}, 89 \% \mathrm{P}, 78 \%$ $\mathrm{K}, 44 \% \mathrm{Ca}, 54 \% \mathrm{Mg}, 67 \% \mathrm{~S}, 82 \% \mathrm{~B}, 77 \% \mathrm{Cu}, 57 \%$ $\mathrm{Fe}, 25 \% \mathrm{Mn}$, and $14 \% \mathrm{Zn}$. These data agree with those obtained by Giovannini et al. (2001), who assessed the total nutrient extraction by branches and bunches of 'Cabernet Sauvignon' vineyards at the Serra Gaúcha region, in southern Brazil, and found nutrient extraction by bunches of $61 \% \mathrm{~N}, 65 \% \mathrm{P}, 73 \% \mathrm{~K}, 31 \% \mathrm{Ca}, 44 \%$ $\mathrm{Mg}, 65 \% \mathrm{~S}, 66 \% \mathrm{~B}, 67 \% \mathrm{Cu}, 81 \% \mathrm{Fe}, 31 \% \mathrm{Mn}$, and $26 \% \mathrm{Zn}$. These authors also observed a higher nutrient extraction by bunches, except for $\mathrm{Ca}, \mathrm{Mg}, \mathrm{Mn}$, and $\mathrm{Zn}$, which were extracted at a higher quantity by branches.

Considering the contents of $\mathrm{N}, \mathrm{P}$, and $\mathrm{K}$ extracted by bunches and branches of 'Niagara Rosada', the total extraction of $\mathrm{N}, \mathrm{P}_{2} \mathrm{O}_{5}$, and $\mathrm{K}_{2} \mathrm{O}$ was 23,11 , and $63 \mathrm{~kg} \mathrm{ha}{ }^{-1}$, respectively. Based on the $\mathrm{P}$ $\left(400 \mathrm{mg} \mathrm{dm}^{-3}\right)$ and $\mathrm{K}\left(3.2 \mathrm{mmol}_{\mathrm{c}} \mathrm{dm}^{-3}\right)$ levels of the soil at the experimental area, an annual application of $130 \mathrm{~kg} \mathrm{ha}^{-1} \mathrm{~N}, 120 \mathrm{~kg} \mathrm{ha}^{-1} \mathrm{P}_{2} \mathrm{O}_{5}$, and $90 \mathrm{~kg} \mathrm{ha}^{-1} \mathrm{~K}_{2} \mathrm{O}$ is

Table 4. Total removal of macro- and micronutrients by pruned branches and harvested bunches of 'Niagara Rosada' grafted onto different rootstocks in three pruning times ${ }^{(1)}$.

\begin{tabular}{|c|c|c|c|c|c|c|c|c|c|c|c|}
\hline \multirow[t]{2}{*}{ Variable } & $\mathrm{N}$ & $\mathrm{K}$ & $\mathrm{P}$ & $\mathrm{Ca}$ & $\mathrm{Mg}$ & $\mathrm{S}$ & B & $\mathrm{Cu}$ & $\mathrm{Fe}$ & $\mathrm{Mn}$ & $\mathrm{Zn}$ \\
\hline & \multicolumn{6}{|c|}{ 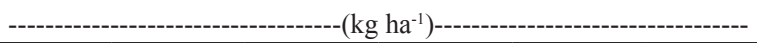 } & \multicolumn{5}{|c|}{---------------------------------(g ha'-1)--------------------------- } \\
\hline \multicolumn{12}{|l|}{ Rootstocks } \\
\hline 'IAC $313 '$ & $22.0 \mathrm{a}$ & $44.2 \mathrm{~b}$ & $4.1 b$ & $13.9 \mathrm{a}$ & $2.9 \mathrm{ab}$ & $2.1 \mathrm{ab}$ & $60 \mathrm{a}$ & $162 b$ & $85 \mathrm{ab}$ & $83 \mathrm{a}$ & $55 \mathrm{a}$ \\
\hline 'IAC 572 ' & $27.3 \mathrm{a}$ & $65.6 \mathrm{a}$ & $5.4 \mathrm{a}$ & $15.4 \mathrm{a}$ & $3.8 \mathrm{a}$ & $2.5 \mathrm{a}$ & $79 a$ & $229 a$ & $103 \mathrm{a}$ & $110 \mathrm{a}$ & $72 \mathrm{a}$ \\
\hline 'IAC 571-6' & $22.6 \mathrm{a}$ & $52.8 \mathrm{ab}$ & $4.7 \mathrm{ab}$ & $13.0 \mathrm{a}$ & $2.9 \mathrm{ab}$ & $2.2 \mathrm{ab}$ & $58 \mathrm{a}$ & $231 \mathrm{a}$ & $94 \mathrm{ab}$ & $77 \mathrm{a}$ & $66 \mathrm{a}$ \\
\hline 'IAC 766' & $22.0 \mathrm{a}$ & $49.6 b$ & $4.3 b$ & $11.0 \mathrm{a}$ & $3.0 \mathrm{ab}$ & $1.9 \mathrm{~b}$ & $54 \mathrm{a}$ & $171 b$ & $72 b$ & $87 \mathrm{a}$ & $51 \mathrm{a}$ \\
\hline '106-8 Mgt' & $22.3 \mathrm{a}$ & $50.6 \mathrm{~b}$ & $4.6 \mathrm{ab}$ & $11.4 \mathrm{a}$ & $2.8 \mathrm{~b}$ & $2.0 \mathrm{~b}$ & $64 \mathrm{a}$ & $168 \mathrm{~b}$ & $74 \mathrm{ab}$ & $91 \mathrm{a}$ & $59 a$ \\
\hline \multicolumn{12}{|l|}{ Pruning times } \\
\hline First (winter) & $24.4 b$ & $44.1 \mathrm{~b}$ & $4.4 \mathrm{~b}$ & $14.9 \mathrm{a}$ & $3.3 b$ & $2.3 \mathrm{a}$ & $49 b$ & $141 b$ & $100 \mathrm{~b}$ & $105 \mathrm{a}$ & $93 a$ \\
\hline Second (summer) & $12.3 \mathrm{c}$ & $31.8 \mathrm{c}$ & $2.5 \mathrm{c}$ & $7.6 \mathrm{~b}$ & $1.8 \mathrm{c}$ & $1.2 \mathrm{a}$ & $40 b$ & $121 b$ & $40 c$ & $61 \mathrm{a}$ & $36 c$ \\
\hline Third (winter) & $33.0 \mathrm{a}$ & $81.8 \mathrm{a}$ & $6.9 \mathrm{a}$ & $16.3 \mathrm{a}$ & $4.0 \mathrm{a}$ & $2.9 \mathrm{a}$ & $99 \mathrm{a}$ & $315 \mathrm{a}$ & $117 \mathrm{a}$ & $102 \mathrm{a}$ & $53 b$ \\
\hline Mean & 23.2 & 52.6 & 4.6 & 12.9 & 3.0 & 2.1 & 62.9 & 192.4 & 85.6 & 89.3 & 60.8 \\
\hline CVrootstocks (\%) & 21.5 & 23.2 & 20.7 & 33.2 & 27.8 & 21.1 & 56.4 & 26.3 & 30.8 & 53.8 & 31.0 \\
\hline CVpruning (\%) & 19.1 & 20.3 & 21.0 & 18.0 & 16.7 & 18.3 & 40.8 & 28.3 & 27.1 & 25.3 & 24.2 \\
\hline
\end{tabular}

${ }^{(1)}$ Means followed by equal letters, in the columns, do not differ by Tukey's test, at $5 \%$ probability. CV, coefficient of variation. 
Table 5. Nutrient uptake by bunches in relation to the total content of nutrients extracted by 'Niagara Rosada' grafted onto different rootstocks in three pruning times ${ }^{(1)}$.

\begin{tabular}{|c|c|c|c|c|c|c|c|c|c|c|c|}
\hline Variable & $\mathrm{N}$ & $\mathrm{K}$ & $\mathrm{P}$ & $\mathrm{Ca}$ & $\mathrm{Mg}$ & $\mathrm{S}$ & B & $\mathrm{Cu}$ & $\mathrm{Fe}$ & $\mathrm{Mn}$ & $\mathrm{Zn}$ \\
\hline \multicolumn{12}{|l|}{ Rootstocks } \\
\hline 'IAC 313' & $70 \mathrm{a}$ & $87 a$ & $75 \mathrm{a}$ & $42 \mathrm{a}$ & $51 \mathrm{a}$ & $66 \mathrm{a}$ & $79 a$ & $74 a$ & $54 \mathrm{a}$ & $27 \mathrm{a}$ & $15 \mathrm{a}$ \\
\hline 'IAC 572' & $68 \mathrm{a}$ & $87 a$ & $73 a$ & $37 \mathrm{a}$ & $48 \mathrm{a}$ & $61 \mathrm{a}$ & $80 \mathrm{a}$ & $78 \mathrm{a}$ & $52 \mathrm{a}$ & $22 \mathrm{a}$ & $11 \mathrm{a}$ \\
\hline 'IAC 571-6' & $75 \mathrm{a}$ & $92 \mathrm{a}$ & $83 a$ & $51 \mathrm{a}$ & $59 a$ & $72 \mathrm{a}$ & $84 a$ & $83 a$ & $63 a$ & $30 \mathrm{a}$ & $16 \mathrm{a}$ \\
\hline 'IAC 766' & $73 a$ & $91 \mathrm{a}$ & $80 \mathrm{a}$ & $46 a$ & $54 \mathrm{a}$ & $69 \mathrm{a}$ & $82 \mathrm{a}$ & $74 \mathrm{a}$ & $59 a$ & $23 \mathrm{a}$ & $15 \mathrm{a}$ \\
\hline '106-8 Mgt' & $71 \mathrm{a}$ & $90 \mathrm{a}$ & $78 \mathrm{a}$ & $43 a$ & $56 \mathrm{a}$ & $67 \mathrm{a}$ & $82 \mathrm{a}$ & $79 a$ & $56 a$ & $23 \mathrm{a}$ & $13 a$ \\
\hline \multicolumn{12}{|l|}{ Pruning times } \\
\hline First (winter) & $60 \mathrm{a}$ & $88 \mathrm{a}$ & $67 b$ & $26 \mathrm{~b}$ & $42 b$ & $56 \mathrm{~b}$ & $68 b$ & $88 \mathrm{a}$ & $32 b$ & $12 b$ & $8 b$ \\
\hline Second (summer) & $62 \mathrm{a}$ & $77 b$ & $66 \mathrm{~b}$ & $35 b$ & $43 b$ & $64 \mathrm{~b}$ & $75 b$ & $80 \mathrm{a}$ & $67 \mathrm{ab}$ & $26 a b$ & $10 \mathrm{~b}$ \\
\hline Third (winter) & $83 a$ & $95 \mathrm{a}$ & $89 \mathrm{a}$ & $63 \mathrm{a}$ & $68 \mathrm{a}$ & $77 \mathrm{a}$ & $91 \mathrm{a}$ & $83 a$ & $74 a$ & $37 \mathrm{a}$ & $27 \mathrm{a}$ \\
\hline Mean & 71 & 89 & 78 & 44 & 54 & 67 & 82 & 77 & 57 & 25 & 14 \\
\hline CVrootstocks (\%) & 20.2 & 18.5 & 22.2 & 20 & 21 & 17.2 & 16.9 & 15.8 & 21.3 & 23.1 & 20 \\
\hline CVpruning (\%) & 19.5 & 17.5 & 27.5 & 26.5 & 19.5 & 24.3 & 21.3 & 20 & 18.9 & 16.5 & 18.2 \\
\hline
\end{tabular}

${ }^{(1)}$ Means followed by equal letters, in the columns, do not differ by Tukey's test, at $5 \%$ probability. CV, coefficient of variation.

recommended. Comparing this recommendation with the $\mathrm{N}, \mathrm{P}$, and $\mathrm{K}$ extraction values of the present study, $18 \% \mathrm{~N}, 10 \% \mathrm{P}$, and $70 \% \mathrm{~K}$ applied as fertilizers are exported by the pruned branches and the harvested bunches, stressing the importance of an adequate annual fertilization. For 'Niagara Rosada' grapevine grafted onto the 'IAC 572' rootstock, the total extraction of $\mathrm{P}$ and $\mathrm{K}$ was around $40 \%$ higher than the extraction observed with 'IAC 313'. In association with soil analysis, these data can contribute to the rationalization of liming and fertilization of 'Niagara Rosada' grapevine. These results also evidenced the need for further research adapted to local conditions, since the application of fertilizers is one of the most important production-cost compounds and has a high influence on grape yield and quality. The proportion of nutrients extracted by 'Niagara Rosada' in relation to vine fertilizer recommendation reinforces the importance of annual fertilization in vineyards.

\section{Conclusions}

1. Fruit yield, biomass accumulation, and nutrient uptake by branches and bunches of 'Niagara Rosada' vineyard vary according to the used rootstock, and 'IAC 572' is more productive than 'IAC 313'.

2. Total nutrientextraction by branches and bunches of 'Niagara Rosada' shows the following nutrient extraction scale: $\mathrm{K}>\mathrm{N}>\mathrm{Ca}>\mathrm{P}>\mathrm{Mg}>\mathrm{S}>\mathrm{Cu}>\mathrm{Mn}>\mathrm{Fe}>\mathrm{B}>\mathrm{Zn}$.

3. Winter pruning favors higher yield, dry matter mass accumulation by branches, and total nutrient content and extraction.

\section{Acknowledgements}

To Fundação de Amparo à Pesquisa do Estado de São Paulo (Fapesp), for financial support.

\section{References}

ABRAHÃO, E.; ALVARENGA, A.A.; FRAGUAS, J.C.; REGINA, M.A.A.; SILVA, V.J. Potencialidades do Município de Lavras-MG para a produção extemporânea de uvas 'Niagara Rosada' para mesa. Ciência e Agrotecnologia, v.26, p.865-868, 2002.

ALBUQUERQUE, T.C.S. de; DECHEN, A.R. Absorção de macronutrientes por porta-enxertos e cultivares de videira em hidroponia. Scientia Agricola, v.57, p.135-139, 2000. DOI: 10.1590/S0103-90162000000100022.

BETTONI, J.C.; GARDIN, J.P.P.; SCHUMACHER, R.L.; RODRIGUES, O.T.; SOUZA, J.A. Qualidade físico-química, extração e exportação de nutrientes da cultivar Cabernet Sauvignon sobre dois porta-enxertos. Ignis: Revista de Engenharias e Inovação Tecnológica, v.2, p.41-53, 2013.

CSIKÁSZ-KRIZSICS, A.; DIÓFÁSI, L. Effects of rootstock-scion combinations on macroelements availability of the vines. Journal of Central European Agriculture, v.9, p.495-504, 2008.

DECHEN, A.R.; HAAG, H.P.; SARRUGE, J.R.; OLIVEIRA, G.D.; GALLO, J.R.; MARTINS, F.P.; SCARANARI, H.S. Acúmulo de nitrogênio, fósforo, potássio, cálcio, magnésio e enxofre pela videira (Vitis labrusca L. x Vitis vinifera L.) cv. 'Niágara rosada', durante um ciclo vegetativo. Anais da Escola Superior de Agricultura Luiz de Queiroz, v.36, p.445-482, 1979. DOI: 10.1590/S0071-12761979000100025.

FERREIRA, D.F. Sisvar: a computer statistical analysis system. Ciência e Agrotecnologia, v.35, p.1039-1042, 2011.

FREGONI, M. Esigenze di elementi nutritivi in viticoltura. Vignevini, v.11, p.27-31, 1984. 
GIOVANNINI, E.; MIELI, A.; FRÁGUAS, J.C.; BARRADAS, C.I.N. Extração de nutrientes pela videira cv. Cabernet Sauvignon na Serra Gaúcha. Pesquisa Agropecuária Gaúcha, v.7, p.27-40, 2001.

HARTMANN, H.T.; KESTER, D.E. Propagación de plantas: principios y prácticas. México: Continental, 1990. 760p.

HERNANDES, J.L.; PEDRO JÚNIOR, M.J.; BLAIN, G.C.; ROLIM, G. de S. Comportamento produtivo da videira 'Niagara Rosada' em diferentes sistemas de condução, com e sem cobertura plástica, durante as safras de inverno e de verão. Revista Brasileira de Fruticultura, v.35, p.123-130, 2013. DOI: 10.1590/S0100-29452013000100015.

IBACACHE, A.G.; SIERRA, C.B. Influence of rootstocks on nitrogen, phosphorus and potassium content in petioles of four Table grape varieties. Chilean Journal of Agricultural, v.69, p.503-508, 2009.

MALAVOLTA, E.; VITTI, G.C.; OLIVEIRA, S.A. de. Avaliação do estado nutricional das plantas: princípios e aplicações. 2.ed. Piracicaba: Potafos, 1997. 319p.

MIELE, A.; RIZZON, L.A.; GIOVANNINI, E. Efeito do porta-enxerto no teor de nutrientes em tecidos da videira 'Cabernet Sauvignon'. Revista Brasileira de Fruticultura, v.33, p.1141-1149, 2009. DOI: 10.1590/S0100-29452009000400031.

MOTA, R.V. da; SOUZA, C.R. de; FAVERO, A.C.; SILVA, C.P.C. e; CARMO, E.L. do; FONSECA, A.; REGINA, M. de A. Produtividade e composição físico-química de bagas de cultivares de uva em distintos porta-enxertos. Pesquisa Agropecuária Brasileira, v.44, p.576-582, 2009. DOI: 10.1590/ S0100-204X2009000600005.

NIKOLAOU, N.; ANGELOPOULOS, K.; KARAGIANNIDIS, N. Effects of drought stress on mycorrhizal and non-mycorrhizal Cabernet Sauvignon grapevine, grafted onto various rootstocks. Experimental Agriculture, v.39, p.241-252, 2003. DOI: 10.1017/S001447970300125X.

PAUlETTO, D.; MORÃO FILHO, F. de A.A.; KLUGE, R.A.; SCARPARE FILHO, J.A. Produção e vigor da videira 'Niágara Rosada' relacionados com o porta-enxerto. Pesquisa Agropecuária Brasileira, v.36, p.115-121, 2001. DOI: 10.1590/ S0100-204X2001000100014.

RIBEIRO, D.F.; CORSATO, C.E.; LEMOS, J.P.; SCARPARE FILHO, J.A. Desenvolvimento e exigência térmica da videira 'Niagara Rosada', cultivada no Norte de Minas Gerais. Revista Brasileira de Fruticultura, v.31, p.890-895, 2009. DOI: 10.1590/S0100-29452009000300036.

RIZK-ALLA, M.S.; SABRY, G.H.; EL-WAHAB, M.A. Influence of some rootstocks on the performance of Red Globe grape cultivar. Journal of American Science, v.7, p.71-81, 2011.
SOUZA, P.V.D. de; FOCHESATO, M.L. Emprego da poda verde para a obtenção de duas safras por ciclo vegetativo em 'Niagara Branca'. Bragantia, v.66, p.611-616, 2007. DOI: 10.1590/ S0006-87052007000400011.

TECCHIO, M.A.; MOURA, M.F.; PAIOLI-PIRES, E.J.; TERRA, M.M. Efeito do porta-enxerto e da época de poda na duração das fases fenológicas e no acúmulo de graus-dia pela videira 'Niagara Rosada'. Revista Brasileira de Fruticultura, v.35, p.1073-1080, 2013. DOI: 10.1590/S0100-29452013000400019.

TECCHIO, M.A.; PAIOLI-PIRES, E.J.; TERRA, M.M.; TEIXEIRA, L.A.J.; LEONEL, S. Características físicas e acúmulo de nutrientes pelos cachos de 'Niagara Rosada' em vinhedos na região de Jundiaí. Revista Brasileira de Fruticultura, v.29, p.621-625, 2007. DOI: 10.1590/S0100-29452007000300038.

TECCHIO, M.A.; TEIXEIRA, L.A.J.; TERRA, M.M.; MOURA, M.F.; PAIOLI-PIRES, E.J. Extração de nutrientes pela videira 'Niagara Rosada' enxertada em diferentes porta-enxertos. Revista Brasileira de Fruticultura, v.33, p.736-742, 2011b. DOI: 10.1590/ S0100-29452011000500103.

TECCHIO, M.A.; TERRA, M.M.; MOURA, M.F.; PAIOLI-PIRES, E.J. Fenologia e acúmulo de graus-dia da videira 'Niagara Rosada' cultivada ao noroeste do Estado de São Paulo. Revista Brasileira de Fruticultura, v.33, p.248-254, 2011a. DOI: 10.1590/ S0100-29452011000500030.

TERRA, M.M.; PIRES, E.J.P.; POMMER, C.V.; BOTELHO, R.V. Produtividade da cultivar de uva de mesa Niagara Rosada sobre diferentes porta-enxertos, em Monte Alegre do Sul - SP. Revista Brasileira de Fruticultura, v.25, p.549-551, 2003. DOI: 10.1590/ S0100-29452003000300049.

TOFANELLI, M.B.D.; BOTELHO, R.V.; PIRES, E.J.P.; VILELA, L.A.F.; RIBEIRO, D.O. Phenology of "Niagara Rosada" grapevines grafted on different rootstocks grown on Cerrado (Brazilian savanna) of Goiás State, Brazil. African Journal of Biotechnology, v.10, p.3387-3392, 2011.

VERDI, A.R.; OTANI, M.N.; MAIA, M.L.; FREDO, C.E.; HERNANDES, J.L. Caracterização socioeconômica e perfil produtivo da produção de uva e vinho artesanal no Município de Jundiaí, Estado de São Paulo. Informações Econômicas, v.40, 2010.

WERLE, T.; GUIMARÃES, V.F.; DALASTRA, I.M.; ECHER, M. de M.; PIO, R. Influência da cianamida hidrogenada na brotação e produção da videira 'Niagara Rosada' na região oeste do Paraná. Revista Brasileira de Fruticultura, v.30, p.20-24, 2008. DOI: 10.1590/S0100-29452008000100006.

WOLPERT, J.A.; SMART, D.R.; ANDERSON, M. Lower petiole potassium concentration at bloom in rootstocks with Vitis berlandieri genetic backgrounds. American Journal of Enology and Viticulture, v.56, p.163-169, 2005. 